NUREG/CR-2650

SAND82-0774

R4

Printed October 1982

\title{
Allowable Shipment Frequencies for the Transport of Toxic Gases Near Nuclear Power Plants
}

David E. Bennett, David C. Heath

\section{Prepared by}

Sandia National Laboratories

Albuquerque, New Mexico 87185 and Livermore, California 94550

for the United States Department of Energy

under Contract DE-AC04-76DP00789

\section{When printing a copy of any digitized SAND} Report, you are required to update the markings to current standards. 


\section{NOTICE}

This report was prepared as an account of work sponsored by an agency of the United States Government. Neither the United States Government nor any agency thereof, or any of their employees, makes any warranty, expressed or implied, or assumes any legal liability or responsibility for any third party's use, or the results of such use, of any information, apparatus product or process disclosed in this report, or represents that its use by such third party would not infringe privately owned rights.

Available from

GPO Sales Program

Division of Technical Information and Document Control

U.S. Nuclear Regulatory Commission

Washington, D.C. 20555

and

National Technical Information Service

Springfield, Virginia 22161 


$$
\begin{gathered}
\text { NUREG/CR-2650 } \\
\text { SAND8 2-0774 } \\
\text { R-4 }
\end{gathered}
$$

Allowable Shipment Frequencies for the Transport of Toxic Gases Near Nuclear Power Plants

David E. Bennett

Nuclear Facility Analysis Division 9415

David C. Heath*

Fuel Cycle Risk Analysis Division 9413

Sandia National Laboratories

Albuquerque, NM 87185

Date Published: October 1982

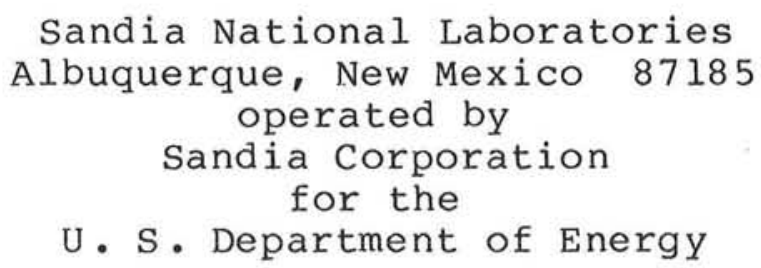

Prepared for

Division of Systems and Reliability Research

Office of Nuclear Regulatory Research

U. S. Nuclear Regulatory Commission

Washington, DC 20555

Under Memorandum of Understanding DOE-40-550-75

NRC FIN No. Al214

* Permanent Address:

School of Operations Research and Industrial Engineering College of Engineering

Cornell University

Ithaca, NY 14853 
Abstract

One part of the safety analysis of offsite hazards for a nuclear power plant is consideration of accidents which could release toxic gases or vapors and thus jeopardize plant safety through incapacitation of the control room operators. The purpose of this work is to provide generic, bounding estimates of the maximum allowable shipping frequencies for the transport of a chemical near the plant, such that the regulatory criteria for the protection of the operators are met. A probabilistic methodology was developed and then applied to the truck and rail transport of an example chemical, chlorine. The current regulatory criteria are discussed in detail. For this study, a maximum allowable probability of occurrence of operator incapacitation of $10^{-5}$ per year was used in the example calculation for each mode of transport. Comprehensive tables of conditional probabilities are presented. Maximum allowable shipping frequencies are then derived. These frequencies could be used as part of a generic, bounding criterion for the screening of toxic hazards safety analyses.

Unless a transport survey assures shipping frequencies within $8 \mathrm{~km}$ of the plant on the order of or lower than $4 /$ week for rail or $35 /$ week for truck, the control room should be isolatable and the shipping frequency then determines the degree of isolation needed. The need for isolation implies the need for toxic chemical detection at the air intake.

For a self-detection case in which the smell threshold is significantly lower than the incapacitation threshold and the control room is isolatable, the corresponding shipping frequencies are 11 /week for rail or $115 /$ week for truck. Self-contained breathing equipment is assumed to be used after 5 minutes. 


\section{TABLE OF CONTENTS}

$\underline{\text { Page }}$

Introduction $\ldots \ldots \ldots \ldots \ldots \ldots \ldots \ldots \ldots \ldots \ldots \ldots \ldots \ldots \ldots \ldots \ldots \ldots \ldots$

Background $\ldots \ldots \ldots \ldots \ldots \ldots \ldots \ldots \ldots \ldots \ldots \ldots \ldots \ldots \ldots \ldots \ldots \ldots$

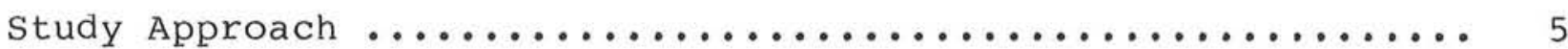

Transportation and Accident statistics ................ 8

Atmospheric Modeling $\ldots \ldots \ldots \ldots \ldots \ldots \ldots \ldots \ldots \ldots \ldots \ldots \ldots \ldots \ldots \ldots$

Control Room Ventilation system ..................... 13

Incapacitation Thresholds $\ldots \ldots \ldots \ldots \ldots \ldots \ldots \ldots \ldots \ldots \ldots \ldots \ldots$

Meteorological Conditions ....................... 15

Model Implementation $\ldots \ldots \ldots \ldots \ldots \ldots \ldots \ldots \ldots \ldots \ldots \ldots \ldots \ldots$

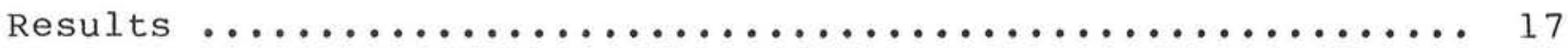

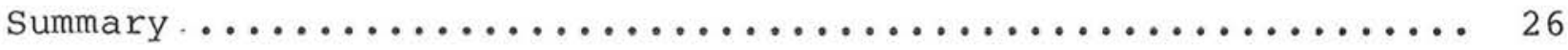

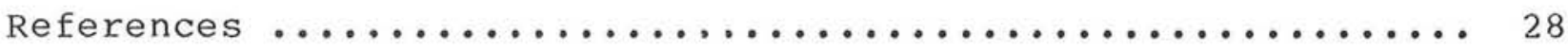




\section{LIST OF TABLES}

Table

$\underline{\text { Page }}$

1. Examples of Weights of Hazardous Chemicals that Require Consideration in Control Room Evaluations (for a $50 \mathrm{mg} / \mathrm{m}^{3}$ Toxic Limit and stable Meteorological

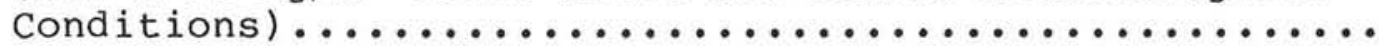

2. Probability of Control Room Operator Incapacitation Given a Toxic Gas Release Along a $16 \mathrm{~km}$ Route (Rail).... 19

3. Probability of Control Room Operator Incapacitation Given a Toxic Gas Release Along a $16 \mathrm{~km}$ Route (Truck) ... 20

4. Probability of Control Room Operator Incapacitation Given a Toxic Gas Release Along a $16 \mathrm{~km}$ Route. Maximum of Probability Values for Four Road Directions

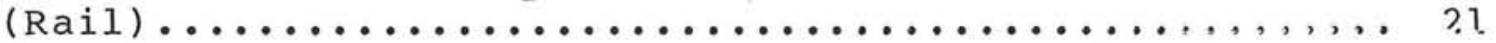

5. Probability of Control Room operator Incapacitation Given a Toxic Gas Release Along a $16 \mathrm{Km}$ Route. Maximum of Probability Values for Four Road Directions

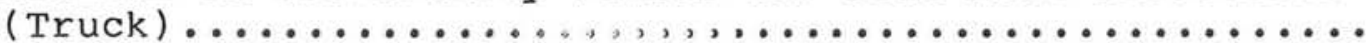

6. Probability of Control Room Operator Incapacitation Given a Toxic Gas Release Along a $16 \mathrm{Km}$ Route. Self Detection Case with Two Minute Delay ........... 23

7. Probability of Control Room Operator Incapacitation Given a Toxic Gas Release Along a $16 \mathrm{~km}$ Route. Maximum of Probability Values for Four Road Directions. Self Detection Case with Two Minute Delay............ 24

8. Maximum Allowable Annual Shipping Frequencies for Rail

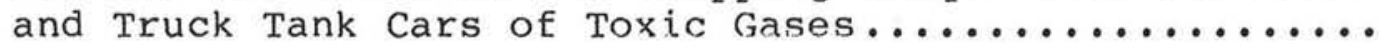




\section{Introduction}

As part of the safety analysis for a nuclear power plant, offsite hazards which could threaten the safe operation or safe shutdown capability of the plant are considered. One of these hazards arising from the transport of hazardous materials in the vicinity of the plant is a transportation accident involving toxic gases (or volatile liquids). The release to the atmosphere of a significant quantity of a toxic material could endanger the plant through incapacitation of the control room operators.

The purpose of this report is to estimate, in a generic manner, an allowable shipping frequency for transport of a chemical in the vicinity of the plant such that the regulatory criteria for the protection of control room operators are met. A probabilistic methodology was developed and then applied to the truck and rail transport of an example chemical, chlorine.

\section{Background}

Several NRC documents describe the requisite safety analyses for accidents involving toxic materials. The broadest guidance is contained in Design Criterion 19 in 10 CFR Part 50, Appendix A, [1] which requires that a control room be provided from which the plant can be operated safely under normal conditions and maintained in a safe condition under accident conditions.

Regulatory Guide (RG) 1.70,[2] "Standard Format and Content of Safety Analysis Reports for Nuclear Power Plants," defines Design Basis Events (DBE's) as those accidents external to the nuclear power plant which have a probability of occurrence of $10^{-7}$ per year or greater and which "have potential consequences serious enough to affect the safety of the plant to the extent that part 100 guidelines could be exceeded." The guide then specifies that the licensee protect against the effects of these DBE's. Accidents involving the storage or transportation of toxic gases or volatile liquids, either on site or off site, would be DBE's and would be considered in evaluating control room habitability.

RG 1.78,[3] "Assumptions for Evaluating the Habitability of a Nuclear Power Plant Control Room During a Postulated Hazardous Chemical Release," provides detailed guidance for the safety analyses of toxic gas transport hazards. According to RG 1.78, a shipment frequency criterion may exclude a chemical from further consideration. Shipments are defined to be frequent if the number per year equals or exceeds 10 for truck traffic, 30 for rail traffic, and 50 for barge traffic. The quantity of the chemical per shipment is specified for a range of distances from the control room to the accident and for three different types of control room ventilation systems. This information is summarized in Table 1 . For a given distance of closest approach along the route and control room type, only shipments whose size exceeds the values in Table 1 
Table 1. Examples of Weights of Hazardous Chemicals that Require Consideration in Control Room Evaluations (for a $50 \mathrm{mg}$ / $\mathrm{m}^{3}$ Toxic Limit and stable Meteorological Conditions)

\begin{tabular}{|c|c|c|c|}
\hline $\begin{array}{l}\text { Distance from } \\
\text { Control Room } \\
\text { (Kilometers) }\end{array}$ & \multicolumn{3}{|c|}{ Weight in Metric Tons } \\
\hline$<0.5$ & $\begin{array}{r}\text { Type A } \\
\text { Control Room }\end{array}$ & $\begin{array}{r}\text { Type B } \\
\text { Control Room }\end{array}$ & $\begin{array}{r}\text { Type C } \\
\text { Control Room }\end{array}$ \\
\hline 0.5 to 0.8 & 0.05 & 0.05 & 0.05 \\
0.8 to 1.1 & 4.1 & 1.0 & 0.05 \\
1.1 to 1.6 & 54 & 4.0 & 0.18 \\
1.6 to 3.2 & 122 & 9.1 & 0.45 \\
3.2 to 4.8 & 590 & 24 & 1.1 \\
4.8 to 6.4 & 1680 & 127 & 5.9 \\
6.4 to 8.0 & 4000 & 354 & 27 \\
\hline
\end{tabular}

Control room types:

Type A - A tight control room having low leakage construction features and the capability of detecting at the fresh air intake those hazardous chemicals stored or transported near the site. Detection of the chemical and automatic isolation of the control room are assumed to have occurred. An air exchange rate of 0.015 per hour is assumed $(0.015$ of the control room air by volume is replaced with outside air in one hour). The control volume is defined as the volume of the entire zone serviced by the control room ventilation system. The assumption that the air exchange rate is less than 0.06 per hour requires verification by field testing.

Type B - Same as Type A, but with an air exchange rate of 0.06 per hour. This value is typical of a control room with normal leakage construction features. The assumption that the air exchange rate is less than 0.06 per hour requires verification by field testing.

Type C - A control room that has not been isolated, has no provision for detecting hazardous chemicals, and has an air exchange rate of 1.2 per hour.

Ref.: Reproduced from Regulatory Guide 1.78, June 1974 [3] . 
need be counted. If this count for a chemical exceeds the above frequency criterion, the licensee must provide protection against accidents involving this chemical. If the frequency criterion is not met, then shipment of this chemical need not be considered. In summary, RG 1.78 specifies size and frequency cutoffs which are used to eliminate chemicals from further consideration. The licensee then provides adequate protection only for those chemicals which exceed both the size and frequency criteria.

RG 1.95, [4] "Protection of Nuclear Power Plant Control Room operators Against an Accidental Chlorine Release," provides specific safety analysis guidance for onsite or offsite releases of chlorine. Maximum single-container inventory quantities are specified for various standoff distances for six different types of control room. The requirements for control room ventilation system performance, emergency planning, and self contained breathing equipment are also specified.

Section 2.2.3, "Evaluation of Potential Accidents," of the Standard Review Plan (SRP), [5] describes the acceptance criteria and review procedures to be used in reviewing a safety analysis. The criteria require that "the design basis events include each postulated type of accident for which a realistic estimate of the probability of occurrence of potential exposures in excess of the 10 CFR Part 100 guidelines exceeds the NRC staff objective of approximately $10^{-7}$ per year." The estimates are allowed to be as realistic as is practicable due to the low probability of occurrence of the events. Further, "a conservative calculation showing that the probability of occurrence of potential exposures in excess of the 10 CFR Part 100 guidelines is approximately $10^{-6}$ per year is acceptable if, when combined with reasonable qualitative arguments, the realistic probability can be shown to be lower." Then the criteria stipulate that the effects of the DBE's on the safety related features of the plant be analyzed and that appropriate mitigation measures be taken. The above quotations are from the 1975 version of the SRP. The wording in the 1981 version[13] is somewhat less clear.

Concerning a quantitative measure that an analyst would use to judge the sufficiency of a safety analysis, Design Criterion 19[1] requires a habitable control room, with the unstated implication that (functioning) operators would be present to take necessary actions. RG 1.70 states the requirement in terms of DBE's whose probability of occurrence exceeds $10^{-7}$ per year and which could lead to releases in excess of the $10 \mathrm{CFR}$ Part 100 guidelines. The SRP states the requirement in terms of probability of occurrence of potential exposures in excess of 10 CFR Part 100 guidelines.

To meet this latter criterion, it would seem that a necessary ingredient of the probabilistic analysis would be the (conditional) probability of exceeding 10 CFR part 100 radioactive release guide- 
lines given incapacitation of the control room operators and given the plant in a stable condition. Estimating such a probability is usually well beyond the scope of a toxic hazards analysis.

RG 1.70 separates the probability of occurrence of the DBE and the consideration of exceeding 10 CFR Part 100 guidelines, while the SRP simply uses the probability of occurrence of potential exposures in excess of 10 CFR Part 100 guidelines. Conceptually the methods that might be used to implement these criteria are quite different. Since probabilistic phenomena like meteorology affect only the probability of exceeding 10 CFR Part 100 guidelines, given a toxic chemical release (the DBE), and do not affect the probability of occurrence of the DBE, the results of analyses using the two different criteria could be significantly different.

With reference to the 10-7/year probability, the 1975 version of the SRP uses the term "realistic estimate" in the statement of the criterion. RG 1.70 , by the use of the phrase "Part 100 guidelines could be exceeded" implies a much more cautious and conservative approach.

RG 1.78 does not explicitly cover a probabilistic methodology which clearly meets the requirements of RG 1.70 and the SRP. Rather, a prescriptive method is presented and there is no discussion of how a safety analysis performed according to RG 1.78 would adequately meet the requirements of RG 1.70 and the SRP.

Prior to July 1981 the question of aggregation of accident frequencies in determining whether the probabilistic criteria are met was not explicitly addressed. The various guides use phrases like "each postulated type of accident" and "for the type of accident under consideration." Considering only toxic hazards, several levels of aggregation might be:

1) Each mode of transport or storage of each chemical, or

2) all modes of transport or storage of each chemical, or

3) all modes of transport or storage of all chemicals.

The choice for level of aggregation will have a significant effect on meeting the regulatory criteria. NRC has been using the last one, all modes for all chemicals, in their license reviews.

The 1981 version[13] of the SRP stipulated that the aggregate risk from all external man-made hazards should also meet the previously quoted probability criteria. The adequacy of the safety analysis of the control room ventilation (habitability) system is then dependent upon the safety analyses of all other external man-made hazards (explosions, fires, etc.). The design 
requirements for the control room ventilation system for toxic hazards protection could be more stringent due to unrelated hazards.

The question that prompted this study was to what extent the shipment frequencies specified in RG 1.78 were overly conservative. Considerable resources might be spent on extensive safety analyses for a multitude of toxic gas shipments, rather than in a focused effort on those chemicals which pose the greatest risk of incapacitating the control room operators. Allocation of resources is an important consideration for both the licensee and the NRC.

The purpose of this report is to provide realistic, but still conservative, estimates of allowable shipping frequencies of toxic gases. The principal concern is truck and rail traffic. Barge traffic was not explicitly considered, although the methodology developed would be applicable. The goal is to relate the allowable shipping frequency for a chemical directly to the regulatory criteria. These more realistic shipping frequencies could be used as screening criteria as part of toxic hazards safety analyses. Current NRC research efforts involving quantitative safety goals and risk allocation may further clarify the application of screening criteria to such safety analyses.

In the following Study Approach section, a clear and simple criterion is presented. Then a probabilistic methodology is developed that includes the effects of meteorology, control room design and standoff distance. As an example, the method is applied to the case of chlorine shipments along a straight route. The question of determining the aggregate risk of operator incapacitation due to "all" toxic materials transportation is addressed only to the extent of suggesting a method for allocating the risk among different chemicals and modes of transport.

\section{Study Approach}

The simplest criterion for evaluating toxic gas hazards analyses is a specification of an acceptable probability per year of operator incapacitation. If the analysis shows a value below the standard, no further protection measures are needed. If the value is higher, various protection measures and strategies would then need to be implemented so as to reduce the probability to at least the level of the criterion. The direct use of a probability of operator incapacitation then separates from any toxic hazards analysis the consideration of exceeding the 10 CFR Part 100 radioactive release guidelines as specified in RG 1.70 and the SRP. Such an analysis for exceeding part 100 guidelines would be quite extensive and would not materially contribute to protection against accidental exposures to toxic gases and vapors. 
However, some allowance should be made in a toxic hazards analysis when using a probability of operator incapacitation derived from a probability of exceeding the Part 100 radioactive release guidelines. That is, it would be overly conservative to use a value of one for the probability of exceeding Part 100 guidelines given incapacitation of operators ( $\mathrm{P}_{100 / \mathrm{O}}$ ). Based on discussions with NRC personnel, [17] a value of 0.1 will be used in this study for $\mathrm{P}_{100 / 0 I}$. If further studies or analyses suggest a different value, the maximum allowable shipping frequencies developed in this work can be simply scaled.

Following the philosophy of the SRP, a higher probability could be used for the criterion in a conservative analysis as compared to a realistic analysis. The use of a factor of 10 difference in the criterion for these two types of analyses would not seem inappropriate.

The selection of numerical values for the criterion depends on the range of accidents to be included. That is, should the criterion cover transportation and storage of a single chemical or all chemicals? Since the transportation and accident data are not available at this time to definitely support aggregate risk estimates, a criterion for a single chemical will be used for this study. As the following methodology and example calculation would be judged conservative, as compared to a realistic or best estimate calculation, a value of $10^{-5}$ per year will be used in the example calculation for an acceptable probability of control room operator incapacitation, based on a value of $10^{-6}$ per year for the maximum allowed probability of exceeding Part 100 guidelines. Since the maximum allowable shipping frequencies are directly proportional to this probability, the results can easily be scaled should a different value for the acceptable incapacitation probability be desired.

A very simple method was used to decompose the overall probability of operator incapacitation (OI) into several constituent parts, one of which is the shipment frequency $F_{S}$. For the transport of a single chemical near the plant, the overall probability $\mathrm{P}_{\mathrm{OI}}$ can be written as:

$$
\mathrm{P}_{\mathrm{OI}}=\mathrm{F}_{\mathrm{S}} \times \mathrm{P}_{\mathrm{A}} \times \mathrm{P}_{\mathrm{R}} \times \mathrm{P}_{\mathrm{I}}
$$

where

$$
\begin{aligned}
\mathrm{P}_{\mathrm{OI}}= & \text { Probability of operator incapacitation } \\
\mathrm{F}_{\mathrm{S}}= & \text { Frequency of shipments (shipments/year) } \\
\mathrm{P}_{\mathrm{A}=} & \text { Probability that a given shipment will } \\
& \text { yield an accident over a specified } \\
& \text { stretch of road (accidents/shipment) }
\end{aligned}
$$




$$
\begin{aligned}
& \mathrm{P}_{\mathrm{R}}=\text { Probability that a large release will } \\
& \text { occur from a given accident (release/ } \\
& \text { accident) } \\
& \mathrm{P}_{\mathrm{I}}=\text { Probability that operators will be in- } \\
& \text { capacitated given that a large release } \\
& \text { occurs along a specified stretch of } \\
& \text { road ( } \mathrm{P}_{\mathrm{OI}} / \mathrm{release).}
\end{aligned}
$$

The probability POI actually represents the expected number of instances of operator incapacitation in a year. Since the expected number of instances is small, it is essentially the same as the probability of an instance. For this study, we restricted the range of the accidents to those which produced a large puff releases; i.e., a sudden, massive release of the entire contents of a tank car. This assumption avoids the complexities of a distribution of release quantities and durations and the dependency of the incapacitation estimate on this distribution.

A simple transportation route geometry was selected. A straight route was assumed to have an offset distance or distance of closest approach D. RG 1.78 requires that accidents which could occur within five miles of the plant be considered in the

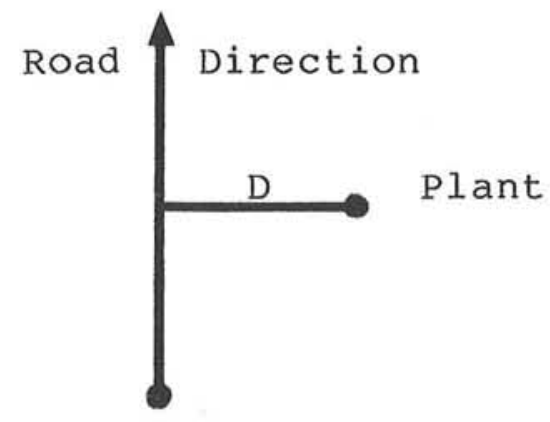

safety analysis. For accidents beyond this distance, a very restricted range of meteorological conditions would be necessary for incapacitation to occur (very stable atmospheric conditions, constant wind direction for the duration of the accident, exact wind direction from accident to the plant, etc.). Therefore, the length of the route was taken to be $16 \mathrm{~km}$ (twice the five mile radius). 
Assuming a constant accident frequency, $\mathrm{P}_{\mathrm{A}}$ can be written as

$$
\mathrm{P}_{\mathrm{A}}=\mathrm{P}_{\mathrm{AK}}(\text { accidents } / \mathrm{km}) \times \mathrm{L}(\mathrm{km} \text { exposed } / \text { shipment })
$$

The overall equation becomes:

$$
\begin{aligned}
\mathrm{P}_{\mathrm{OI}}= & \mathrm{F}_{\mathrm{S}} \text { (shipments/year) } \mathrm{x} \\
& \mathrm{P}_{\mathrm{AK}}(\text { accidents } / \mathrm{km}) \mathrm{x} \\
& \mathrm{L}(\mathrm{km} \text { exposed/shipment) } \mathrm{x} \\
& \mathrm{P}_{\mathrm{R}}(\text { large release/accident }) \mathrm{x} \\
& \mathrm{P}_{\mathrm{I}}(\mathrm{OI} / \text { large release })
\end{aligned}
$$

The last term is actually the probability of oI given a large release anywhere along the $16 \mathrm{~km}$ route.

\section{Transportation and Accident Statistics}

Transportation data and accident data that are sufficient to perform risk analyses are generally not available for a wide variety of toxic chemicals. Even for a chemical which has been studied extensively, like chlorine, only summary production and transport data are available. Local data which could be used to support site specific analyses are gathered at relatively high cost and may not predict future trends in shipping rates.

In terms of the previous probability equation, $P_{0 I}$ can be calculated given $\mathrm{F}_{\mathrm{S}}$, or vice versa. Since one cannot a priori develop a "generic" shipping rate for an individual route, the maximum acceptable value for $\mathrm{P}_{0 I}$ will be used to estimate the maximum allowable shipping frequency. If the analysis is sufficiently conservative, this frequency is site independent and hence can be used as a generic screening criteria. That is, if a local transport survey showed a higher shipping frequency, a site specific analysis should be performed to assess the level of protection needed.

Several studies $[8,14,15,16]$ have considered tank car accidents, their expected frequency of occurrence, and their severity. Overall accident rates for truck and rail tank cars were compiled as part of a detailed study[14] of accident dynamics: 
Accident Rate

(per tank car-km)

Truck

$1.6 \times 10^{-6}$

Rail

$1.0 \times 10^{-6}$

These numbers are comparable to those quoted in NUREG-0170, [6] which studied the shipment of radioactive materials in urban environs. In NUREG-0170, the quoted truck rate was slightly lower: $1 \times 10^{-6}$ per car-km.

Several studies of dynamic accident analyses for tank cars have included the full range of potential failure mechanisms: fire, crush, impact and puncture.[14,15] The results are summarized in terms of general accident categories: minor, moderate, severe, extra severe and extreme. Since this study and the example calculation for chlorine use only a two box model for characterizing potential releases (no release and a large release), the risk from small releases must be lumped into the probability of the large release. This resulting probability will be somewhat larger than a realistic estimate of just a massive release. The probabilities for a severe or worse accident were estimated by sandia to be:[14]

Accident Rate
(per tank car-km)

Truck

Rail
$8 \times 10^{-9}$

$9 \times 10^{-8}$

These values would be about a factor of 4 to 6 higher for moderate or worse accidents.

Simmons, Erdmann and Naft studied the risk of catastrophic spills of toxic chemicals, more specifically chlorine.[8] Their rail accident data leads to a probability for a large release of $5 \times 10^{-8}$ per tank car-km, based on data for all hazardous cargo and assuming an average shipment distance of $450 \mathrm{~km}$.[16] For a projected 55,000 shipments per year, [16] this accident probability corresponds to slightly more than one large release per year. In comparison, the rate from the Battelle report is about the same, while the sandia accident rate leads to just over two per year. The authors[8] point out that the historical data for chlorine suggests a large release rate about 10 times lower $(0.1$ releases per year versus about 1 per year). The Battelle report [16] also discusses this historical discrepancy.

For use in the example calculation, the accident rate for truck transport from the Sandia study will be used. For rail transport, the slightly lower accident rate from the Simmons, Erdman and 
Naft, and Battelle studies will be used, as the historical data on chlorine would tend to support a lower value. The values for $P_{R}$, the probability of a large release, given an accident, are:

$\begin{array}{ll} & \underline{\mathrm{P}}_{\mathrm{R}} \\ \text { Truck } & .005 \\ \text { Rail } & .05\end{array}$

indicating that severe accidents for trains are an order of magnitude more frequent than for trucks. This is supported in a general sense by rail accident data; for instance, that over $80 \%$ of all train accidents involve derailments. [15]

One heuristic way of checking the estimate of the probability of a large release is to consider the total quantity of hazardous materials (HM) shipments per year. The National Transportation Safety Board estimates about 218 billion ton-miles of HM/year. [7] Using about 50 tons per shipment yields an annual shipping distance of seven billion $\mathrm{km} / \mathrm{year}$. Using an estimate of about 100 major accidents per year which involve large releases (based on one author's rough but conservative recollection of current events) yields an annual probability of a large release of $1.4 \times 10^{-8}$ large releases $/ \mathrm{km}$, which is comparable to the rates suggested earlier from other sources.

Atmospheric Modeling

For this work, a relatively detailed analysis was made of the probability of operator incapacitation given a large release on the $16 \mathrm{~km}$ route. The location of the accident along the route was assumed to be uniformly distributed; that is, no preferential accident sites were assumed.

A Gaussian puff was used to describe the atmospheric transport of the toxic gas after release from the transport container. The initial size of the release is characterized ${ }^{[3]}$ by $\sigma_{0}$ :

$$
\sigma_{0}(\text { meters })=\left[\left(\frac{1}{2 \pi^{3}}\right)^{1 / 2} \frac{M}{\rho}\right]^{1 / 3}
$$

where $M$ is the mass released and $\rho$ is the gas density.

For tank cars of pressurized liquid which flash to vapor upon rupture of the tank, the mass released is proportional to the flashing fraction. The remainder, which did not flash to vapor, is a supercooled liquid and will boil off over some period of time. For chlorine, the flashing fraction ranges from about $17 \%$ at $20^{\circ} \mathrm{C}\left(70^{\circ} \mathrm{F}\right)$ to about $35 \%$ at $70^{\circ} \mathrm{C}\left(160^{\circ} \mathrm{F}\right)$. These fractions are 
based on the adiabatic decompression of the pressurized liquid. [8] Further liquid will flash to vapor as the spilled liquid contacts the terrain surrounding the accident site; this contribution to the initial puff is highly dependent on the accident scenario. The boiloff will form a plume, which follows the initial puff. For this study, it is assumed that the entire inventory of the tank car is contained in the initial puff and that there is no plume. This conservative assumption will maximize the peak concentration seen in the control room. For truck and rail tank cars of chlorine, the values for $\sigma_{0}$ are $9.25 \mathrm{~m}$ and $15 \mathrm{~m}$, corresponding to 20 and 90 tons/tank car, respectively.

The formulation for a neutrally bouyant Gaussian puff is given in terms of a unit concentration ( $C=1$ corresponds to a $100 \%$ concentration):

$$
C=\lambda_{0} \exp \left\{-\frac{1}{2} \cdot\left[\frac{(X-U t)^{2}+Y^{2}}{\sigma_{O}^{2}+\sigma_{1}^{2}}+\frac{Z^{2}}{\sigma_{O}^{2}+\sigma_{3}^{2}}\right]\right\}
$$

where:

$$
\lambda_{0}=\left\{1+\frac{\sigma_{3}^{2}}{\sigma_{0}^{2}}\right\}^{-1 / 2}\left\{1+\frac{\sigma_{1}^{2}}{\sigma_{0}^{2}}\right\}^{-1}
$$

The distances $X, Y, Z$ are measured from the release point. The time $t$ is measured from the start of the release and $U$ is the wind speed in $\mathrm{m} / \mathrm{s} .[3]$ The wind direction is assumed constant during and after an accident and in the $\mathrm{X}$ direction.

The dispersion parameters $\sigma_{1}$ and $\sigma_{3}$ are defined by $[8]$

$$
\begin{aligned}
& \sigma_{1}=C_{1}(U t)^{\beta_{1}} \\
& \sigma_{3}=C_{3}(U t)^{\beta_{3}}
\end{aligned}
$$

The parameters $C_{1}, C_{3}, \beta_{1}$, and $\beta_{3}$ for the three stablility categories are summarized below: [8] 


\section{Dispersion Parameters}

$\underline{C}_{1} \quad \underline{\beta}_{1} \quad \underline{C}_{3} \quad \underline{\beta}_{3}$

$\begin{array}{lllll}\text { Unstable } & 0.27 & 0.91 & 0.11 & 1.0 \\ \text { Neutral } & 0.13 & 0.91 & 0.11 & 0.80 \\ \text { Stable } & 0.078 & 0.91 & 0.11 & 0.72\end{array}$

The geometry of the route and plant locations, accident site, and wind direction is shown below:

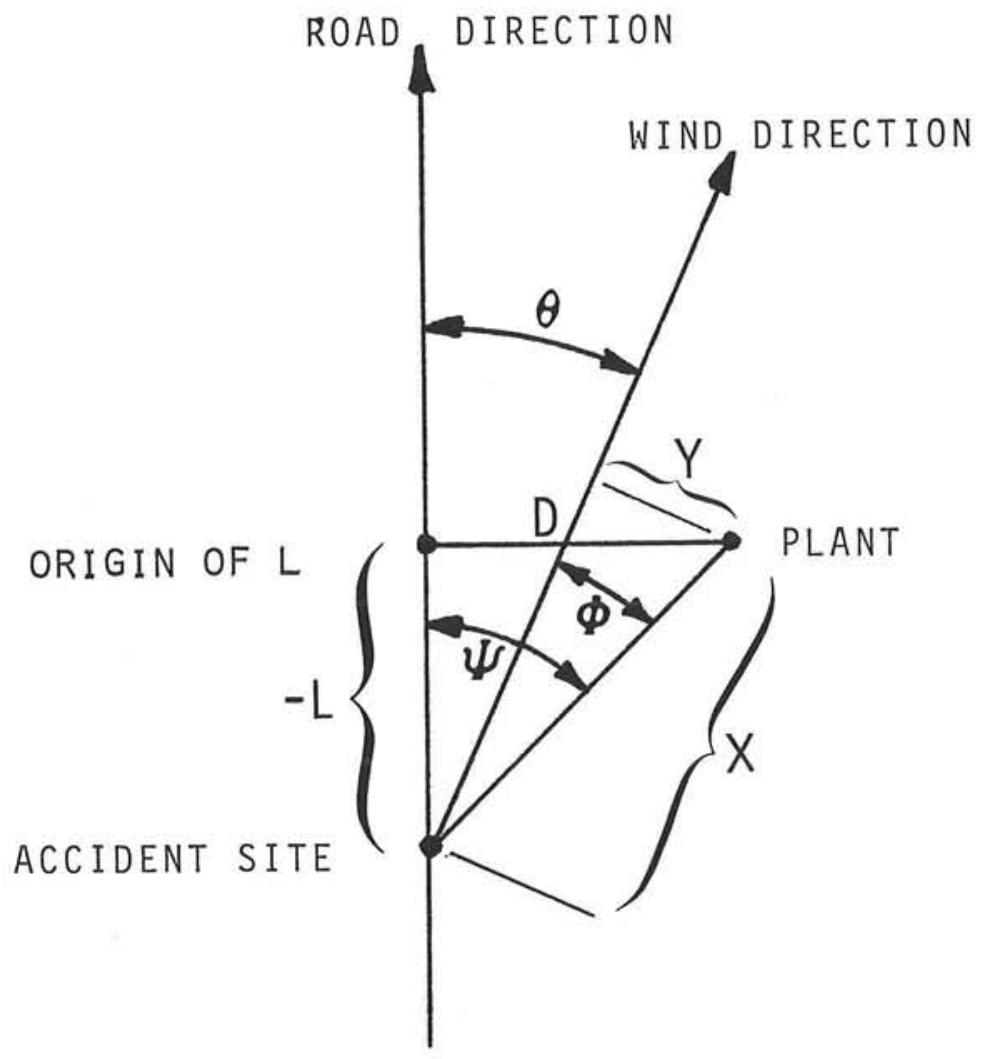

The along-wind distance $\mathrm{X}$ and the cross wind distance $\mathrm{Y}$ can be expressed in terms of the distance along the route $L$, the offset distance $\mathrm{D}$ and the angle between the road and wind direction:

$$
\begin{aligned}
& X=-L \cos \theta+D \sin \theta \\
& Y=D \cos \theta+L \sin \theta
\end{aligned}
$$


For this study, six offset distances D (distance of closest approach) were considered: $500,750,1000,1500,2000$, and $3000 \mathrm{~m}$. The specification of wind speed and direction, road direction, stability class, offset distance, and accident location is sufficient to calculate the concentration profile at the plant site as a function of time.

\section{Control Room Ventilation System}

The control room ventilation system draws in contaminated air, which leads to the exposure of the operators. The concentration inside the control room, $C_{I}$, can be expressed by means of a differential equation involving the outside concentration $\mathrm{C}_{\mathrm{O}}$ and the ventilation system air exchange rate $\mathrm{R}:$ [9]

$$
\frac{d C_{I}}{d t}=R\left(C_{O}-C_{I}\right)
$$

where $R$ is in units of control room volumes/time unit.

As described in the notes in Table 1 , there are different types of control room ventilation systems. For an unisolated control room, no provision is made for detection of toxic chemicals in the intake and thus a constant air exchange rate is maintained throughout an accident sequence. For an isolatable control room, the outside air intake is closed upon detection of a toxic chemical in the intake and remains closed as the cloud passes the plant. The intake reopens when the outside concentration is reduced to a negligible level.

To perform the calculation, the times of arrival and departure of the outside cloud are needed:

\begin{tabular}{ll} 
Time & \multicolumn{1}{c}{ Event } \\
$\mathrm{T}_{1}$ & $\begin{array}{l}\text { Outside concentration reaches a threshold } \\
\text { level }(0.1 \mathrm{ppm})\end{array}$ \\
$\mathrm{T}_{2}$ & $\begin{array}{l}\text { Outside concentration reaches the detector } \\
\text { level ( } 1.0 \mathrm{ppm})\end{array}$ \\
$\mathrm{T}_{3}$ & $\begin{array}{l}\text { Outside concentration falls below the } \\
\text { detector level }\end{array}$ \\
$\mathrm{T}_{4}$ & $\begin{array}{l}\text { Outside concentration falls below the } \\
\text { threshold level }\end{array}$
\end{tabular}


A simple function for the air exchange rate was chosen:

\begin{tabular}{lll}
\multicolumn{1}{c}{ Time } & \multicolumn{2}{c}{ Air Exchange Rate } \\
\cline { 2 - 2 }$<\mathrm{T}_{2}$ & $\mathrm{R}=\mathrm{R}_{1}$ & open rate \\
$\mathrm{T}_{2} \leq \mathrm{t} \leq \mathrm{T}_{3}$ & $\mathrm{R}=\mathrm{R}_{2}$ & isolated rate \\
$\mathrm{t}>\mathrm{T}_{3}+\Delta$ & $\mathrm{R}=\mathrm{R}_{3}$ & exhaust rate
\end{tabular}

The open rate is typically one volume per hour. The closing and opening of the intake were modeled as a ramp of one second duration. A delay $\Delta$ of 30 seconds was assumed for opening of the system to an exhaust rate, which could be larger than the normal rate. Five cases were considered in this study to cover the range of control room ventilation system designs:

\begin{tabular}{llll} 
Case & $\mathrm{R}_{1}$ & $\mathrm{R}_{2}$ & $\mathrm{R}_{3}$ \\
\hline & & & \\
1. & 1. & 1. & 1. \\
2. & 1. & .06 & 1. \\
3. & 1. & .06 & 2. \\
4. & 1. & .015 & 1. \\
5. & 1. & .015 & 2.
\end{tabular}

The increased exhaust rate does not affect the peak concentration in the control room, but reduces the total dose to which the operator is exposed.

Incapacitation Thresholds

While a multitude of toxic chemicals are shipped in bulk by truck and train, a few, like chlorine and ammonia, stand out as suspected dominant contributors to the overall risk. Note that local transport and chemical manufacturing activities could result in other chemicals being the principal hazards at a particular site. Since chlorine has a much lower incapacitation level (10 ppm) than ammonia ( $45 \mathrm{ppm})$, it was chosen as the "example" chemical for this study. ${ }^{10}$ Thus $\mathrm{P}_{\mathrm{I}}$ (OI/large release), mentioned earlier, is the probability of the concentration in the control room equaling or exceeding $10 \mathrm{ppm}$.

The physiological and toxicological effects[10] of chlorine are concentration dependent. That is, incapacitation is assumed to have occurred when the exposure concentration reaches the specified level, independent of the dose or integrated exposure. Ammonia and many other chemicals fall into this concentration dependent 
class of effects. The other broad class of toxicological effects is dose dependency. Carbon monoxide, vinyl chloride, nitrogen dioxide and acetophenone are gases with dose-dependent incapacitation effects. In this study, the data needed for the probability of exceeding a dose threshold were also collected. A dose of $10^{5}$ ppm-seconds was chosen, as it is somewhat conservative. A few chemicals have lower dose thresholds for immediate incapacitation, but most have higher thresholds ( $\left.10^{6} \mathrm{ppm}-\mathrm{sec}\right)$.

\section{Meteorological Conditions}

Since the shipment frequency estimates calculated in this study are to be used to screen safety analyses for adequacy and to determine whether further analysis is required, a conservative set of meteorological conditions were assumed.

The meteorological data for the site are given in terms of the probabilities of wind direction, wind speed and stability class. The wind roses for all U. S. reactor sites were examined and the one with largest peak for a single direction was used:[11]

\section{Direction Probability Direction Probability}

Toward N

NNE

NE

ENE

E

ESE

SE

SSE
.048

.046

.043

.038

.070

.160

.265

.052
S

SSW

SW

WSW

W

WNW

NW

NNW
.013

.006

.009

.013

.035

.092

.055

.055

This rose also has the feature that about $72 \%$ of the time the wind blows into the east half plane.

The combined probabilities for wind speed and atmospheric stability class were obtained from several such distributions in WASH-1400.[12] Some sites had a high probability of neutral and stable conditions and others had a predominance of low wind speeds. Since no one site had both features, a composite site with a predominance of both neutral and stable atmospheric conditions and low wind speeds was constructed: 
Wind Speed $(\mathrm{m} / \mathrm{s})$

\begin{tabular}{|c|c|c|c|c|c|c|}
\hline \multicolumn{3}{|r|}{ In } & \multirow{2}{*}{\multicolumn{3}{|c|}{ Stability Class }} & \multirow[b]{2}{*}{ Total } \\
\hline Range & Value & Used & & & & \\
\hline $0-1$ & 0.5 & & .0051 & .1231 & .3594 & .4876 \\
\hline $1-2$ & 1.5 & & .0072 & .0775 & .1481 & .2328 \\
\hline $2-3$ & 2.5 & & .0046 & .0341 & .0582 & .0969 \\
\hline $3-4$ & 3.5 & & .0045 & .0260 & .0485 & .0790 \\
\hline $4-5$ & 4.5 & & .0026 & .0119 & .0202 & .0347 \\
\hline $5-6$ & 5.5 & & .0024 & .0106 & .0133 & .0263 \\
\hline $6-7$ & 6.5 & & .0009 & .0055 & .0046 & .0110 \\
\hline$>7$ & 8.0 & & .0014 & .0173 & .0130 & .0317 \\
\hline & & Total & .0287 & .3060 & .6653 & 1.000 \\
\hline
\end{tabular}

Probability

Model Implementation

The methodology and data needed to calculate $\mathrm{P}_{\mathrm{I}}$ and hence $\mathrm{F}_{\mathrm{S}}$ have been described above. A computer program was written to perform the calculations and prepare concentration and dose histograms. From these histograms, values for $\mathrm{P}_{I}$ were obtained. In the following tables, both the probability that the peak inside concentration equals or exceeds $10 \mathrm{ppm}$ and the probability that the exposure dose equals or exceeds $10^{5}$ ppm-seconds are presented.

The one remaining factor in the analysis is the direction of the road with respect to the assumed wind rose. Several trial computations were made for 16 possible road directions, equally spaced. For a given road direction, the plant lies to the right of the road (refer to previous figure showing wind-road geometry). In general ENE or NNW gave the highest probabilities and SSE the lowest, for the assumed wind rose. For the final calculations four representative road directions were used: ENE, ESE, SSE, and NNW.

In the methodology described above, specific properties of the example chemical (in our case, chlorine) are needed in only two places. First, the shipment size and the ambient density of the initial gas cloud $f i x$ the variable $\sigma_{O}$, the initial size of the puff. Second, the incapacitating exposure concentration for chlorine is used to determine whether incapacitation occurred for each individual case or combination of conditions. The transport of the gas cloud through the atmosphere (Gaussian puff) and through 
the ventilation system treats the toxic material as a neutrally bouyant ideal gas, which is independent of specific physical or chemical properties.

Note that refinements in atmospheric transport modeling like negative or positive cloud bouyancy, or site specific terrain features like wooded areas were not included in this analysis methodology. Inclusion of these latter phenomena is unlikely to significantly affect the results.

The assumption of constant wind direction allows the differential equations to be solved using a simple integrating routine. A far more complex finite element formulation for the mass and momentum distributions and a finite difference solution technique would be required if varying wind directions were included.

The air intake (or intakes) for the ventilation system are modeled as a single point receptor, as this is the minimum requirement for any plant. Some plants have two widely separated, independent inlets, with uncontaminated air (hopefully) being generally available at one of them. Since the purpose of this work is to develop generic or site independent allowable shipping frequencies, dual inlet systems were not considered. If they were, an additional modeling complexity would be introduced that would not materially enhance the applicability of the results. It should be pointed out that larger accident-plant distances, less stable atmospheric conditions, and to a lesser extent slow wind speeds all contribute to lateral dispersion of the cloud. Hence many of the individual cases (combinations of conditions) might still lead to incapacitation for a dual inlet system. While the specific calculations for dual inlet systems were not performed, it would probably require a considerable separation (more than a few hundred meters) to significantly reduce the probability of operator incapacitation.

An associated issue is the rescue of the plant operators by other onsite personnel or by the operators from the second unit of a two unit site. Due to the large cloud size (at the plant) and the relatively low concentration needed for incapacitation, personnel not in an isolated enclosure would have a very high probability of incapacitation $(\sim 1)$ and thus not be available for rescue or emergency work. Again, since the purpose of this work is to provide generic and conservative shipping frequencies, there does not appear to be a defensible generic method for allowing credit for emergency response.

$\underline{\text { Results }}$

The results for rail tank cars are presented in Table 2 and for truck tank cars in Table 3. The values for $P_{I}$ are shown for the two incapacitation means, six offset distances, four road directions, five control room types, and three exposure durations. 
The variation in road direction leads to a change by a factor of two to (at most) four in the probability values. The wide range of probabilities in the assumed wind rose does not lead to a strong dependence on road direction because of the large distances at which the plant is vulnerable and the cross wind diffusion of the cloud. Since the goal of this study is to provide generic shipping frequencies which are independent of off-site features like road direction, the appropriate probability is the maximum of the values for the four road directions. These reduced sets of probabilities are presented in Table 4 for rail shipments and Table 5 for truck shipments.

Increasing the offset distance of the plant from the road does not greatly reduce the probability. This arises because, for the combinations of wind speed, stability class and accident location along the route which produced concentrations above $10 \mathrm{ppm}$, the level was significantly above the $10 \mathrm{ppm}$ threshold.

Reducing the duration of the exposure significantly reduces the probability of incapacitation. This is seen by comparing the "2-MIN," "5-MIN," and "MAX" columns in the various tables. Cessation of the exposure would require the use of self contained breathing equipment with sufficient capacity for several hours of use.

Another interesting result concerns the distance (from the accident site to the plant) beyond which no combination of wind direction, wind speed or stability class produced incapacitating levels in the control room. These distances are listed in Tables 4 and 5. Remember that the road considered extends in each direction only $8 \mathrm{~km}$. The isolation of the control room and limiting the exposure by the use of breathing equipment can significantly reduce this maximum "distance of concern." For a given control room type and exposure duration, increased standoff distance, in many cases, has little effect. From a generic, site independent point of view, there is not a reasonable standoff distance criterion such that operator incapacitation is precluded; that is, $\mathrm{P}_{\mathrm{I}}$ is identically zero.

The above calculations are based on the use of an outside detector and automatic isolation of the control room upon reaching the set point of the detector (1 ppm). Another scenario for operator protection involves detection by personnel and a delay in isolating the control room. Detection (by smell) could occur either by the control room operators or by other plant personnel. Since outside personnel would detect the presence of the chernical considerably before those inside, detection is assumed to occur when the outside concentration reaches $2 \mathrm{ppm}$. A two minute delay is then assumed before control room isolation occurs; this represents the time needed for assessment and communication. An additional five minute delay is assumed for the time required for the control room operators to begin using self contained breathing equipment. The probabilities of operator incapacitation 
TABLE 2

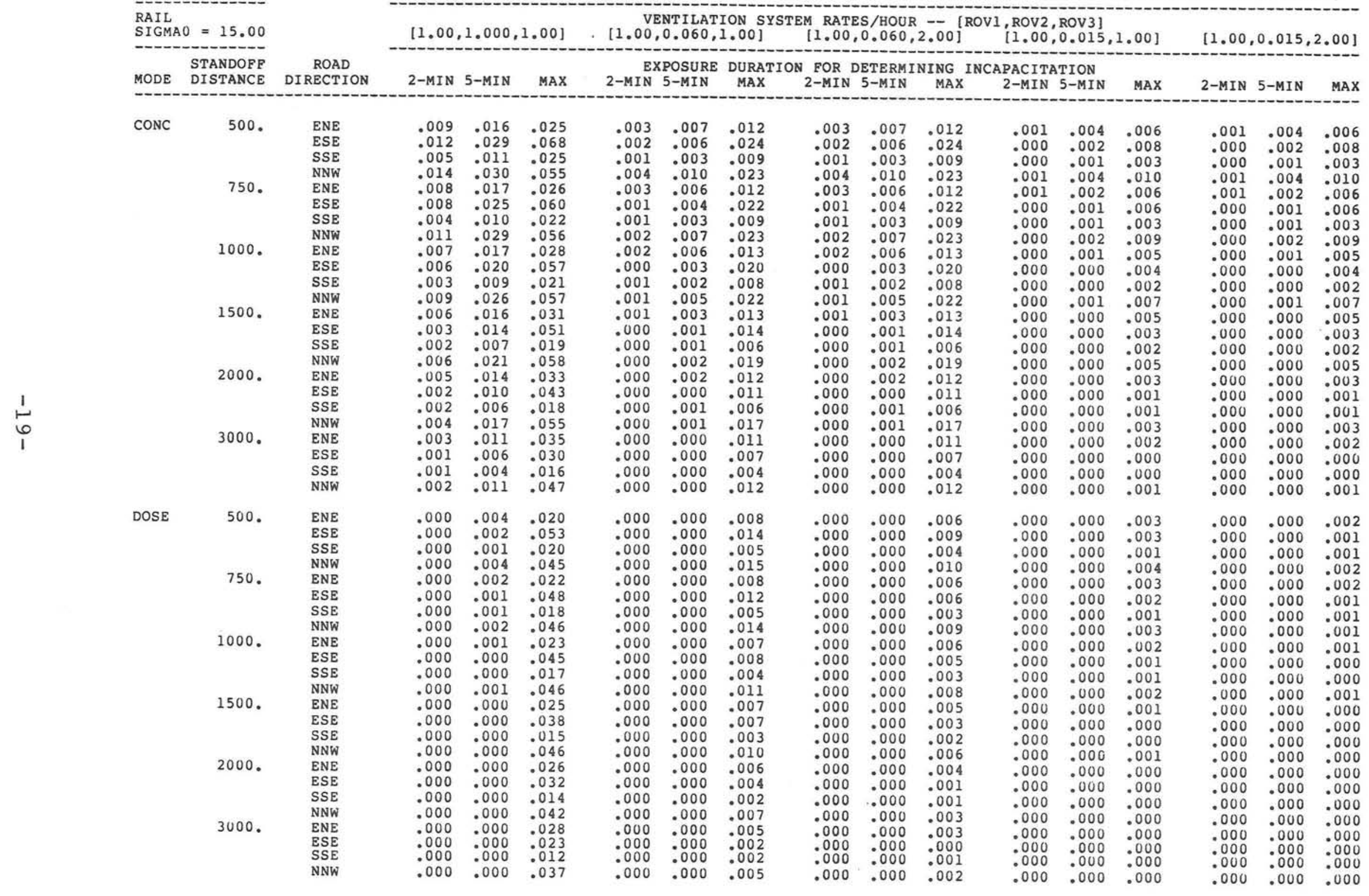

PROBABILITY OF CONTROL ROOM OPERATOR INCAPACITATION GIVEN A TOXIC GAS RELEASE ALONG A 16 KM ROUTE. 


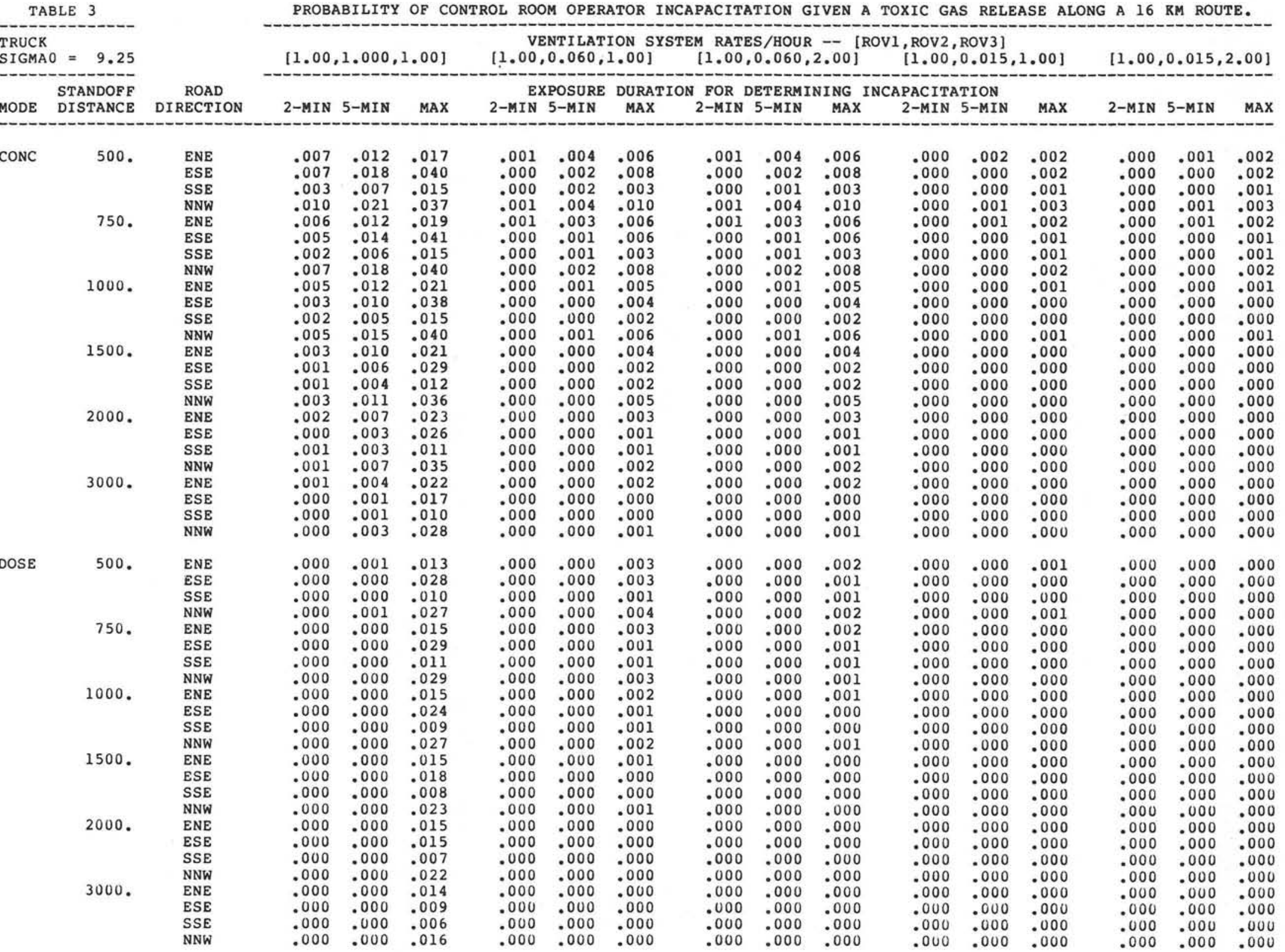


TABLE 4 PROBABILITY OF CONTROL ROOM OPERATOR INCAPACITATION GIVEN A TOXIC GAS RELEASE ALONG A 16 KM ROUTE. MAXIMUM OF PROBABILITY VALUES FOR FOUR ROAD DIRECTIONS.

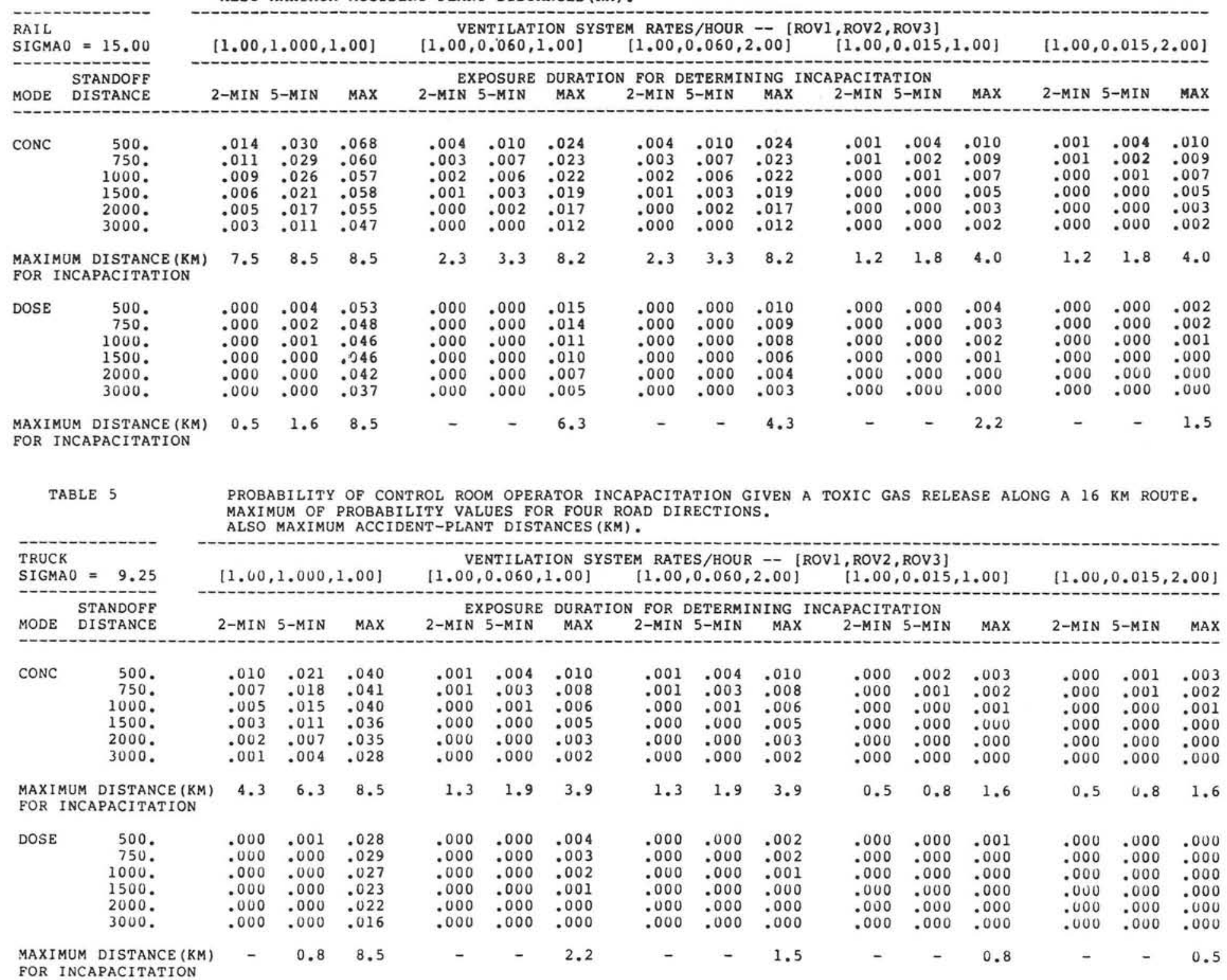


for this scenario for a ventilation system with normal isolation (infiltration rate of 0.06 volumes/hour) are listed in Table 6 in the columns labeled "5-MIN". These probabilities are higher than the corresponding values in the previous tables. Table 7 lists the maximum probability values independent of road direction and the maximum distances for incapacitating accidents.

A comment should be made about values in the probability tables reported as zero. No distinction is made between a value smaller than 0.0005 (which rounds to zero) and a value which is identically zero. The relative error in $\mathrm{P}_{I}$ increases as $\mathrm{P}_{I}$ decreases, due to the small number of cases which lead to incapacitation. The probabilities reported are believed to be accurate to within a few digits in the last place, due to computational accuracies.

The maximum probability values from Tables 4,5 and 7 were used to estimate the maximum allowable shipping frequencies for truck and rail transport. In Table 8, the frequencies are given for the five control room types and for two exposure durations (five minutes and maximum). For each combination, the range of values reflects the dependence on standoff distance. These maximum allowable shipping frequencies are based on a criterion of $10^{-5}$ per year as the maximum acceptable probability of operator incapacitation.

The principal result is that the frequencies are lower for rail than truck, contrary to RG 1.78 . This follows directly from the accident frequency and severity data, which indicates that the probability of a large release is larger for rail than truck.

A second result is that for unisolated control rooms, the allowable shipping frequency would appear to be below the licensee's ability to assuredly exclude the chemical on the basis of $h$ is traffic survey (e.g., about 4 per week for rail). To do so the survey would have to extend out to $8 \mathrm{~km}$ for both rail and truck transport.

A critical assumption in using these transport frequencies for plants with isolated control rooms is that there is a detector for the chemical under consideration. But what was the reason for analyzing an isolatable control room prior to showing the need for isolation? It would seem that unless the licensee's survey shows assuredly a frequency below that adequate for an unisolated control room, then detection is required and the traffic frequency sets the degree of isolation needed. This type of a protection strategy is markedly different from that in RG 1.78 . 
TABLE 6

PROBABILITY OF CONTROL ROOM OPERATOR INCAPACITATION GIVEN A TOXIC GAS RELEASE ALONG A 16 KM ROUTE.

SELF DETECTION CASE WITH TWO MINUTE DELAY.

\begin{tabular}{|c|c|c|c|c|c|c|c|c|}
\hline \multirow[b]{2}{*}{ MODE } & \multirow[b]{2}{*}{$\begin{array}{l}\text { STANDOFF } \\
\text { DISTANCE }\end{array}$} & \multirow[b]{2}{*}{$\begin{array}{c}\text { ROAD } \\
\text { DIRECTION }\end{array}$} & \multicolumn{3}{|c|}{$\begin{array}{l}\text { TRUCK } \\
\text { SIGMAO }=9.25\end{array}$} & \multicolumn{3}{|c|}{$\begin{array}{l}\text { RAIL } \\
\text { SIGMAO }=15.00\end{array}$} \\
\hline & & & $\begin{array}{l}\text { EXPOSL } \\
2-M I N\end{array}$ & $\begin{array}{l}\text { RE DUI } \\
5-M I N\end{array}$ & $\begin{array}{r}\text { MAX } \\
\text { MAN }\end{array}$ & $\begin{array}{c}\text { FOR DETER } \\
2-M I N\end{array}$ & $\begin{array}{l}\text { MINING } \\
5-M I N\end{array}$ & $\begin{array}{l}\text { INCAPACITATION } \\
\text { MAX }\end{array}$ \\
\hline CONC & $\begin{array}{l}2000 \text {. } \\
3000 \text {. }\end{array}$ & $\begin{array}{l}\text { ENE } \\
\text { ESE } \\
\text { SSE } \\
\text { NNW } \\
\text { ENE } \\
\text { ESE } \\
\text { SSE } \\
\text { NNW } \\
\text { ENE } \\
\text { ESE } \\
\text { SSE } \\
\text { NNW } \\
\text { ENE } \\
\text { ESE } \\
\text { SSE } \\
\text { NNW } \\
\text { ENE } \\
\text { ESE } \\
\text { SSE } \\
\text { NNW } \\
\text { ENE } \\
\text { ESE } \\
\text { SSE } \\
\text { NNW }\end{array}$ & $\begin{array}{l}.008 \\
.008 \\
.004 \\
.011 \\
.007 \\
.005 \\
.003 \\
.008 \\
.006 \\
.003 \\
.002 \\
.006 \\
.004 \\
.002 \\
.001 \\
.004 \\
.002 \\
.001 \\
.001 \\
.002 \\
.001 \\
.000 \\
.000 \\
.001\end{array}$ & $\begin{array}{l}.009 \\
.009 \\
.004 \\
.013 \\
.008 \\
.006 \\
.004 \\
.010 \\
.008 \\
.004 \\
.003 \\
.008 \\
.005 \\
.002 \\
.002 \\
.004 \\
.003 \\
.001 \\
.001 \\
.002 \\
.001 \\
.000 \\
.000 \\
.000\end{array}$ & $\begin{array}{l}.010 \\
.015 \\
.006 \\
.018 \\
.010 \\
.011 \\
.005 \\
.015 \\
.010 \\
.008 \\
.004 \\
.012 \\
.008 \\
.004 \\
.003 \\
.008 \\
.006 \\
.001 \\
.002 \\
.004 \\
.003 \\
.000 \\
.001 \\
.001\end{array}$ & $\begin{array}{l}.011 \\
.014 \\
.006 \\
.017 \\
.010 \\
.011 \\
.005 \\
.015 \\
.009 \\
.008 \\
.004 \\
.012 \\
.007 \\
.005 \\
.003 \\
.008 \\
.006 \\
.003 \\
.002 \\
.006 \\
.003 \\
.001 \\
.001 \\
.003\end{array}$ & $\begin{array}{l}.012 \\
.019 \\
.008 \\
.022 \\
.013 \\
.014 \\
.007 \\
.019 \\
.013 \\
.011 \\
.006 \\
.016 \\
.010 \\
.006 \\
.004 \\
.011 \\
.008 \\
.003 \\
.003 \\
.007 \\
.004 \\
.001 \\
.001 \\
.003\end{array}$ & $\begin{array}{l}.016 \\
.032 \\
.012 \\
.032 \\
.017 \\
.030 \\
.012 \\
.032 \\
.017 \\
.026 \\
.011 \\
.030 \\
.017 \\
.018 \\
.008 \\
.025 \\
.017 \\
.014 \\
.008 \\
.022 \\
.014 \\
.008 \\
.005 \\
.015\end{array}$ \\
\hline DOSE & $\begin{array}{l}2000 \text {. } \\
3000 \text {. }\end{array}$ & $\begin{array}{l}\text { ENE } \\
\text { ESE } \\
\text { SSE } \\
\text { NNW } \\
\text { ENE } \\
\text { ESE } \\
\text { SSE } \\
\text { NNW } \\
\text { ENE } \\
\text { ESE } \\
\text { SSE } \\
\text { NNW } \\
\text { ENE } \\
\text { ESE } \\
\text { SSE } \\
\text { NNW } \\
\text { ENE } \\
\text { ESE } \\
\text { SSE } \\
\text { NNW } \\
\text { ENE } \\
\text { ESE } \\
\text { SSE } \\
\text { NNW }\end{array}$ & $\begin{array}{l}.000 \\
.000 \\
.000 \\
.000 \\
.000 \\
.000 \\
.000 \\
.000 \\
.000 \\
.000 \\
.000 \\
.000 \\
.000 \\
.000 \\
.000 \\
.000 \\
.000 \\
.000 \\
.000 \\
.000 \\
.000 \\
.000 \\
.000 \\
.000\end{array}$ & $\begin{array}{l}.001 \\
.000 \\
.000 \\
.001 \\
.000 \\
.000 \\
.000 \\
.000 \\
.000 \\
.000 \\
.000 \\
.000 \\
.000 \\
.000 \\
.000 \\
.000 \\
.000 \\
.000 \\
.000 \\
.000 \\
.000 \\
.000 \\
.000 \\
.000\end{array}$ & $\begin{array}{l}.007 \\
.006 \\
.003 \\
.009 \\
.006 \\
.004 \\
.002 \\
.007 \\
.005 \\
.002 \\
.002 \\
.004 \\
.003 \\
.001 \\
.001 \\
.002 \\
.001 \\
.000 \\
.000 \\
.001 \\
.000 \\
.000 \\
.000 \\
.000\end{array}$ & $\begin{array}{l}.002 \\
.001 \\
.001 \\
.001 \\
.001 \\
.000 \\
.000 \\
.000 \\
.000 \\
.000 \\
.000 \\
.000 \\
.000 \\
.000 \\
.000 \\
.000 \\
.000 \\
.000 \\
.000 \\
.000 \\
.000 \\
.000 \\
.000 \\
.000\end{array}$ & $\begin{array}{l}.003 \\
.001 \\
.001 \\
.003 \\
.002 \\
.000 \\
.001 \\
.001 \\
.001 \\
.000 \\
.000 \\
.001 \\
.000 \\
.000 \\
.000 \\
.000 \\
.000 \\
.000 \\
.000 \\
.000 \\
.000 \\
.000 \\
.000 \\
.000\end{array}$ & $\begin{array}{l}.012 \\
.020 \\
.008 \\
.022 \\
.012 \\
.017 \\
.007 \\
.021 \\
.012 \\
.012 \\
.006 \\
.017 \\
.011 \\
.009 \\
.005 \\
.014 \\
.009 \\
.005 \\
.003 \\
.010 \\
.006 \\
.002 \\
.002 \\
.005\end{array}$ \\
\hline
\end{tabular}


PROBABILITY OF CONTROL ROOM OPERATOR INCAPACITATION GIVEN A TOXIC GAS RELEASE ALONG A 16 KM ROUTE.

MAXIMUM OF PROBABILITY VALUES FOR FOUR ROAD DIRECTIONS.

SELF DETECTION CASE WITH TWO MINUTE DELAY.

ALSO MAXIMUM ACCIDENT-PLANT DISTANCES(KM) 。

\begin{tabular}{|c|c|c|c|c|c|c|c|}
\hline & & \multicolumn{3}{|c|}{$\begin{array}{l}\text { TRUCK } \\
\text { SIGMAO }=9.25\end{array}$} & \multicolumn{3}{|c|}{$\begin{array}{l}\text { RAIL } \\
\text { SIGMAO }=15.00\end{array}$} \\
\hline MODE & $\begin{array}{l}\text { STANDOFF } \\
\text { DISTANCE }\end{array}$ & \multicolumn{3}{|c|}{ EXPOSURE DURATION } & \multicolumn{2}{|c|}{$\begin{array}{c}\text { FOR DETERMINING } \\
2-\text { MIN 5-MIN }\end{array}$} & $\begin{array}{l}\text { INCAPACITATION } \\
\text { MAX }\end{array}$ \\
\hline CONC & $\begin{array}{l}500 . \\
750 \\
1000 . \\
1500 \\
2000 . \\
3000 .\end{array}$ & $\begin{array}{l}.011 \\
.008 \\
.006 \\
.004 \\
.002 \\
.001\end{array}$ & $\begin{array}{l}.013 \\
.010 \\
.008 \\
.005 \\
.003 \\
.001\end{array}$ & $\begin{array}{l}.018 \\
.015 \\
.012 \\
.008 \\
.006 \\
.003\end{array}$ & $\begin{array}{l}.017 \\
.015 \\
.012 \\
.008 \\
.006 \\
.003\end{array}$ & $\begin{array}{l}.022 \\
.019 \\
.016 \\
.011 \\
.008 \\
.004\end{array}$ & $\begin{array}{l}.032 \\
.032 \\
.030 \\
.025 \\
.022 \\
.015\end{array}$ \\
\hline \multicolumn{2}{|c|}{ FOR INCAPACITATION } & 4.3 & 4.3 & 4.3 & 7.8 & 7.8 & 8.2 \\
\hline DOSE & $\begin{array}{l}500 . \\
750 . \\
1000 . \\
1500 . \\
2000 . \\
3000 .\end{array}$ & $\begin{array}{l}.000 \\
.000 \\
.000 \\
.000 \\
.000 \\
.000\end{array}$ & $\begin{array}{l}.001 \\
.000 \\
.000 \\
.000 \\
.000 \\
.000\end{array}$ & $\begin{array}{l}.009 \\
.007 \\
.005 \\
.003 \\
.001 \\
.000\end{array}$ & $\begin{array}{l}.002 \\
.001 \\
.000 \\
.000 \\
.000 \\
.000\end{array}$ & $\begin{array}{l}.003 \\
.002 \\
.001 \\
.000 \\
.000 \\
.000\end{array}$ & $\begin{array}{l}.022 \\
.021 \\
.017 \\
.014 \\
.010 \\
.006\end{array}$ \\
\hline $\begin{array}{l}\text { MAXIMO } \\
\text { FOR IN }\end{array}$ & $\begin{array}{l}\text { M DISTANCE (KM) } \\
\text { CAPACITATION }\end{array}$ & 0.7 & 1.0 & 2.8 & 1.2 & 1.6 & 6.3 \\
\hline
\end{tabular}


Table 8. Maximum Allowable Annual Shipping Frequencies for Rail and Truck Tank Cars of Toxic Gases.

Ventilation System Rates

Self Detection Case

2 Minute Delay

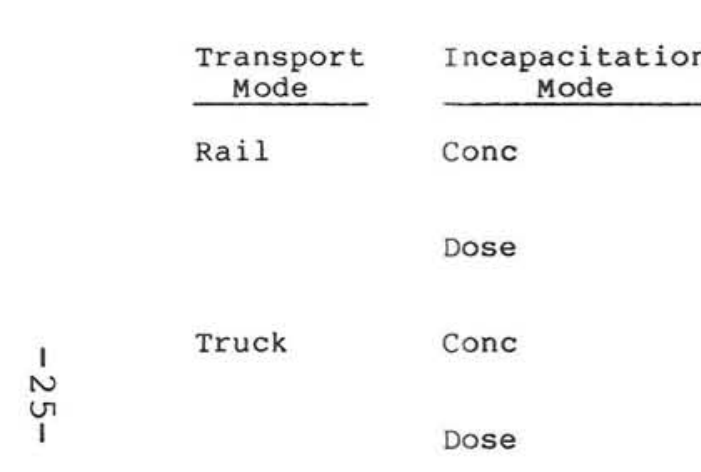

\begin{tabular}{|c|c|c|c|c|c|c|c|c|c|c|c|}
\hline \multicolumn{2}{|c|}{$(1,1,1)$} & \multicolumn{2}{|c|}{$(1, .06,1)$} & \multicolumn{2}{|c|}{$(1, .06,2)$} & \multicolumn{2}{|c|}{$(1, .015,1)$} & \multicolumn{2}{|c|}{$(1, .015,2)$} & \multirow{2}{*}{\multicolumn{2}{|c|}{$(1, .06,1)$}} \\
\hline & & & Exposur & Durat & ion for & Determin & ing Inc & acitati & & & \\
\hline 5-Min & $\operatorname{Max}$ & $5-M$ in & Max & $5-M$ in & $\operatorname{Max}$ & 5-Min & $\operatorname{Max}$ & 5-Min & Max & $5-\mathrm{M}$ in & $\operatorname{Max}$ \\
\hline $\begin{array}{l}420- \\
1100\end{array}$ & $\begin{array}{l}180- \\
270\end{array}$ & $\begin{array}{l}1250- \\
\text { UNL }\end{array}$ & $\begin{array}{l}520- \\
1000\end{array}$ & $\begin{array}{l}1250- \\
\text { UNL }\end{array}$ & $\begin{array}{l}520- \\
1000\end{array}$ & $\begin{array}{c}3100- \\
\text { UNL }\end{array}$ & $\begin{array}{l}1250- \\
6300\end{array}$ & $\begin{array}{l}3100- \\
\text { UNL }\end{array}$ & $\begin{array}{l}1250- \\
6300\end{array}$ & $\begin{array}{l}570- \\
3100\end{array}$ & $\begin{array}{l}390- \\
830\end{array}$ \\
\hline $\begin{array}{l}3100- \\
\text { UNL }\end{array}$ & $\begin{array}{l}240- \\
340\end{array}$ & UNL & $\begin{array}{l}830- \\
2500\end{array}$ & UNL & $\begin{array}{l}1250- \\
4200\end{array}$ & UNL & $\begin{array}{l}3100- \\
\text { UNL }\end{array}$ & UNL & $\begin{array}{l}6300- \\
\text { UNL }\end{array}$ & $\begin{array}{c}4200- \\
\text { UNL }\end{array}$ & $\begin{array}{l}570- \\
2100\end{array}$ \\
\hline $\begin{array}{l}3700- \\
20000\end{array}$ & $\begin{array}{l}1900- \\
2800\end{array}$ & $\begin{array}{l}20000- \\
\text { UNL }\end{array}$ & $\begin{array}{l}7800- \\
39000\end{array}$ & $\begin{array}{c}20000- \\
\text { UNL }\end{array}$ & $\begin{array}{l}7800- \\
39000\end{array}$ & $\begin{array}{c}39000- \\
\text { UNL }\end{array}$ & $\begin{array}{c}26000- \\
\text { UNL }\end{array}$ & $\begin{array}{l}39000- \\
\text { UNL }\end{array}$ & $\begin{array}{l}26000- \\
\text { UNL }\end{array}$ & $\begin{array}{l}6000- \\
78000\end{array}$ & $\begin{array}{r}4300- \\
26000\end{array}$ \\
\hline $\begin{array}{c}78000- \\
\text { UNL }\end{array}$ & $\begin{array}{l}2800- \\
4900\end{array}$ & UNL & $\begin{array}{l}20000- \\
\text { UNL }\end{array}$ & UNL & $\begin{array}{l}39000- \\
\text { UNL }\end{array}$ & UNL & $\begin{array}{l}78000- \\
\text { UNL }\end{array}$ & UNL & UNL & $\begin{array}{c}78000- \\
\text { UNL }\end{array}$ & $\begin{array}{l}8700- \\
\text { UNL }\end{array}$ \\
\hline
\end{tabular}

Notes: 1. UNL $=$ Unlimited.

2. Ranges of values are for standoff distances of $500 \mathrm{~m}$ to $3000 \mathrm{~m}$. 
As the licensee develops a map of projected route locations and directions and a meteorological data base for his site, the allowable transport frequencies could be based on detailed values similar to those in Tables 2 through 5, rather than on the maximum "screening or global" values used to construct Table 8 . For example, a more uniform wind rose would decrease $P_{I}$ by about a factor of two from the maximum.

This report addresses the rail and truck transport of a chemical as if they were independent. That is, a separate assessment is made for each mode to assure compliance with the probabilistic criterion on operator protection. One method for allocating allowable shipping frequencies among the various modes of transport is to use fractional frequencies. Define $F_{T}, F_{R}$, and $\mathrm{F}_{\mathrm{B}}$ as the actual shipping frequencies for truck rail, and barge transport, respectively. Similarly, define $N_{T}, N_{R}$ and $N_{B}$ as the maximum allowable shipping frequencies. An acceptance criterion for all transport of a single chemical might be:

$$
\frac{\mathrm{F}_{\mathrm{T}}}{\mathrm{N}_{\mathrm{T}}}+\frac{\mathrm{F}_{\mathrm{R}}}{\mathrm{N}_{\mathrm{R}}}+\frac{\mathrm{F}_{\mathrm{B}}}{\mathrm{N}_{\mathrm{B}}} \leq 1 .
$$

Such a measure properly allocates the risk among the various modes of transport. A similar extension would allow consideration of more than one chemical.

\section{Summary}

This report presents a methodology for estimating allowable shipping frequencies for the truck and rail transport of toxic gases near a nuclear power plant. The resulting frequencies are based on a criterion that the probability of incapacitating the control room operators be less than $10^{-5}$ year for each chemical. Using conservative accident and meteorological data, calculations were done for an example chemical, chlorine. Because of these conservative assumptions, the allowable shipping frequencies could be used to screen safety analyses of nuclear plants to determine whether a more detailed analysis of toxic gas hazards is warranted.

The principal conclusions are that:

1. Rail transport is more hazardous than truck transport.

2. Offset distance from the route to the plant is generally of minor significance for offset distances less than 2 to $3 \mathrm{~km}$. 
3. For unisolated control rooms, rail and truck accidents at $8 \mathrm{~km}$ can lead to operator incapacitation.

4. Unless a transport survey assures shipping frequencies on the order of or lower than $4 /$ week for rail or $35 /$ week for truck, the control room should be isolatable and the shipping frequency then determines the degree of isolation needed.

5. For a self-detection case in which the smell threshold is significantly lower than the incapacitation threshold and the control room is isolatable, the corresponding shipping frequencies are 11 /week for rail or $115 /$ week for truck. Self-contained breathing equipment is assumed to be used after 5 minutes.

Except when detection by smell is adequate, the need for control room isolation implies the need for chemical detection in the control room air intake. The protection strategy of first determining the need for control room isolation and then the degree of isolation is markedly different from that in RG 1.78 . 
$\underline{\text { References }}$

1. U. S. Code of Federal Regulations, Title 10, Part 50, Appendix A, General Design Criteria 19; Office of the Federal Register, General Services Administration, Washington, DC, 1981

2. Standard Format and Content of Safety Analysis Reports for Nuclear Power Plants, LWR Edition, U.S. Nuclear Regulatory Commission (USNRC), Office of Standards Development (SD), Regulatory Guide 1.70, Revision 3, November 1978

3. Assumptions for Evaluating the Habitability of a Nuclear Power Plant Control Room During a Postulated Hazardous Chemical Release, USNRC/SD, Regulatory Guide 1.78, June 1974 .

4. Protection of Nuclear Power Plant Control Room Operators Against An Accidental Chlorine Release, USNRC/SD, Regulatory Guide 1.95, Revision 1, January 1977 .

5. Standard Review Plan for the Review of Safety Analysis Reports for Nuclear Power Plants, USNRC, Office of Nuclear Reactor Regulation (NRR), Washington, DC, NUREG-75/087, 1975.

6. Final Environmental statement on the Transportation of Radioactive Materials by Air and Other Modes, USNRC/SD, NUREG-0170, Vol. 1, December 1977.

7. Safety Effectiveness Evaluation - Federal and State Enforcement Efforts in Hazardous Materials Transportation by Truck, National Transportation Safety Board, NTSB-SEE-81-2, February 1981.

8. Simmons, J. A., Erdmann, R. C., Naft, D. N., Risk of Catastrophic Spills of Toxic Chemicals, California University, Los Angeles, CA, UCLA-ENG-7425, May 1974 .

9. Bennett, D. E., and Finley, N. C., Hazards to Nuclear Power Plants from Nearby Accidents Involving Hazardous Materials A Preliminary Assessment, Sandia National Laboratories, Albuquerque, NM, NUREG/CR-1748, SAND80-2334, April 1981.

10. Smith, G. J., and Bennett, D. E., Models for the Estimation of Incapacitation Times Following Exposures to Toxic Gases or Vapors, Sandia National Laboratories, Albuquerque, NM, NUREG/CR-1741, SAND80-2226, December 1980.

11. Sprung, J. L., Steck, G. P., and Frazier, A. W., Correlations Between Wind Flow and Population Location at 67 Light Water Nuclear Power plant Sites, Sandia National Laboratories, Albuquerque, NM, SAND78-0557, October 1978 . 
12. Reactor Safety Study, WASH-1400, USNRC, October 1975.

13. Standard Review Plan for the Review of Safety Analysis Reports for Nuclear Power Plants, USNRC/NRR, Washington, DC, NUREG-0800, July 1981 .

14. Clarke, R. K., Foley, J. T., Hartman, W. F., Larson, D. W., Severities of Transportation Accidents, Sandia National Laboratories, Albuquerque, NM, SLA-74-001, July 1976.

15. Dennis, A. W., Foley, J. T., Hartman, W. F., Larson, D. W., Severities of Transportation Accidents Involving Large Packages, Sandia National Laboratories, Albuquerque, NM, SAND77-0001, May 1978 .

16. Andrews, W. B., An Assessment of the Risk of Transporting Liquid Chlorine By Rail, Battelle Pacific Northwest Laboratory, Richland, WA, PNL-3376.

17. Private Communication from K. G. Murphy, Division of Systems and Reliability Research, office of Nuclear Regulatory Research, U. S. Nuclear Regulatory Commission, Washington, DC. 
U. S. NRC Distribution Contractor (CDSI) (360)

7300 Pearl street

Bethesda MD 20014

335 copies for $\mathrm{R} 4$

25 copies for NTIS

Professor David C. Heath (5)

School of Operations Research and Industrial Engineering College of Engineering

Cornell University

Ithaca NY 14853

Kenneth G. Murphy (5)

Division of Systems and Reliability Research

U. S. Nuclear Regulatory Commission

Washington, DC 20555

$\begin{array}{ll}3311 & \text { D. R. Parker } \\ 9400 & \text { A. W. Snyder } \\ 9410 & \text { D. J. McCloskey } \\ 9412 & \text { J. W. Hickman } \\ 9413 & \text { N. R. Ortiz } \\ 9413 & \text { N. C. Finley } \\ 9414 & \text { G. B. Varnado } \\ 9414 & \text { D. M. Ericson, Jr. } \\ 9415 & \text { D. C. Aldrich (25) } \\ 9415 & \text { D. E. Bennett (25) } \\ 9440 & \text { D. A. Dahlgren } \\ 9443 & \text { D. C. Carlson } \\ 9780 & \text { R. M. Jefferson } \\ 9781 & \text { R. E. Luna } \\ 9781 & \text { J. M. Taylor } \\ 9782 & \text { R. T. Reese } \\ 8214 & \text { M. A. Pound } \\ 3141 & \text { L. J. Erickson (5) } \\ 3151 & \text { W. L. Garner (3) }\end{array}$

